\title{
PENYESUAIAN DIRI DI LINGKUNGAN SEKOLAH PADASISWA KELAS XI SMA PASUNDAN 2 BANDUNG
}

\author{
Sulisworo Kusdiyati, \& Lilim Halimah, Faisaluddin \\ Fakultas Psikologi \\ Universitas Islam Bandung, \\ Jl. Tamansari no 1 Bandung, \\ sulisworo.kusdiyati@gmail.com
}

\begin{abstract}
The purpose of this study is to obtain empirical data about the picture of adjustment at class XI Pasundan high school 2. The methodology in this research used descriptive study. The population of this study was 340 students in grade XI and the samples were 181 students. The samples were taken used cluster random sampling technique by looking at the Krejcie table. Collecting data used adjustment scale developed by researchers based on the theory of adjustment from Schneiders. Data were obtained in the form of ordinal data and analyzed using the median and Percentage (\%). The results showed that as many as 86 students $(47.5 \%)$ could be well adjusted, and 95 students $(52.5 \%)$ could not be well adjusted. In addition the result showed that students with authoritative parenting and were not influenced by peers is the most well adjusted.
\end{abstract}

Keywords: Adjustment, Adolescent, Parenting Style, Peer Group.

\begin{abstract}
Abstrak
Maksud dan tujuan diadakannya penelitian ini adalah untuk mendapatkan data empiris mengenai gambaran penyesuaian diri di sekolah pada siswa kelas XI SMA Pasundan 2. Penelitian ini merupakan penelitian deskriptif, dan penelitian ini merupakan penelitian sampel. Populasi dari penelitian ini adalah 340 siswa kelas XI, dan diambil sampel dengan menggunakan teknik cluster random sampling dengan melihat tabel Krejcie. Pengumpulan data menggunakan alat ukur berupa skala penyesuaian diri di sekolah yang dikembangkan oleh peneliti berdasarkan teori penyesuaian diri dari Schneiders. Data yang diperoleh berupa data ordinal, dengan pengolahan data menggunakan perhitungan median, dan Porsentase $(\%)$. Berdasarkan hasil pengolahan data, maka didapatkan
\end{abstract}


hasil bahwa sebanyak 86 siswa (47,5\%) dapat menyesuaikan diri dengan baik, dan 95 siswa $(52,5 \%)$ tidak dapat menyesuaikan diri dengan baik. Serta didapatkan pula hasil bahwa siswa dengan pola asuh Authoritative serta tidak terpengaruh oleh teman sebaya merupakan faktor paling positif yang dapat menyebabkan individu tersebut dapat menyesuaikan diri dengan baik.

Kata kunci : Penyesuaian Diri, Pola Asuh, Remaja, Teman Sebaya.

\section{Pendahuluan}

Visi dari SMAPasundan 2 adalah mengembangkan pendidikan yang berkualitas unggul dalam bidang keilmuan, motivasi, mentalitas berdasarkan keislaman dan budaya sunda yang mampu bersaing di tingkat lokal, nasional dan internasional. Namun demikian pada kenyataannya terdapat suatu fenomena yakni banyak siswa yang tidak mampu menyesuaikan diri dengan situasi sosial. Data mengenai pelanggaran yang dilakukan siswa dalam kurun waktu 1 semester, yaitu dari bulan Juli 2007 hingga desember 2007, terdapat 117 pelanggaran atau 38\% dari 309 siswa kelas X, 187 pelanggaran atau $43 \%$ dari 431 siswa kelas XII dan 214 pelanggaran atau 63\% dari 340 siswa kelas XI. Jenis pelanggaran-pelanggaran tersebut dibagi mejadi 5 aspek yaitu mengenai motivasi belajar, masalah pribadi, masalah sosial-ekonomi, masalah karier, dan masalah penyesuaian diri. Diketahui bahwa masalah penyesuaian diri menempati peringkat teratas dibanding keempat aspek yang lainnya. Pelanggaranpelanggaran yang termasuk di dalam aspek penyesuaian diri diantara membolos, terlambat datang ke sekolah, lalai dalam mengerjakan tugas, mencontek, berpakaian tidak sesuai dengan aturan sekolah, merokok, bahkan minum minuman beralkohol dan menggunakan obat terlarang di lingkungan sekolah. Pelanggaran yang dilakukan siswa kelas X yang jumlahnya mencapai 38\% siswa, 26\% diantaranya adalah masalah penyesuaian diri. Terdapat $43 \%$ pelanggaran yang dilakukan anak kelas XII, 23\% adalah masalah penyesuaian diri. Sedangkan pada siswa kelas XI, dari 63\% pelanggaran yang terjadi, 52\%-nya masalah penyesuaian diri.

Menurut seorang guru BP yang khusus menangani siswa kelas XI, masalah penyesuaian diri yang paling banyak terjadi adalah masalah membolos dan pelanggaran dalam mengenakan pakaian yang tidak sesuai dengan peraturan sekolah. Selain membolos dan mengenakan pakaian yang tidak sesuai dengan peraturan sekolah, banyak juga siswa kelas XI yang datang terlambat, mengobrol dengan teman sebangku 
di kelas ketika sedang pelajaran, tidak mengerjakan tugas-tugas yang diberikan oleh pihak sekolah, bahkan ada beberapa siswa yang melanggar peraturan sekolah dengan merokok atau mengkonsumsi obat terlarang di lingkungan sekolah. Menurut guru BP tersebut, pelanggaran sekolah dilakukan oleh lebih dari setengah siswa di sekolah tersebut, namun untuk pelanggaran-pelanggaran berat seperti membolos hingga berkali-kali dan merokok biasanya hanya dilakukan oleh siswa-siswa tertentu saja.

Diperoleh informasi dari wawancara tersebut, bahwa sebenarnya SMA tersebut telah memiliki peraturan tertulis mengenai tata tertib siswa di sekolah, yaitu:

1. Hadir di sekolah sebelum bel berbunyi

2. Harus ada di sekolah selama waktu sekolah berlangsung

3. Siswa yang keluar di waktu sekolah, harus seizin guru piket

4. Kehadiran kurang dari $90 \%$ akan dikenai skorsing, tidak naik kelas, atau dikembalikan kepada orang tua

5. Pakaian harus dimasukkan ke dalam (kecuali pakaian pramuka putri dan baju koko), lengan baju tidak boleh dilipat, tidak boleh terlalu besar atau sempit, model standar, panjang rok semata kaki, menggunakan sepatu hitam, dan kaos kaki putih.

6. Bila sakit tidak boleh menggunakan sweater atau jaket di lingkungan sekolah

7. Seragam olah raga hanya digunakan pada saat olah raga

8. Sejumlah larangan misal: merusak, menulis atau mencoret-coret meja, dinding, kursi, dan pintu.

Menurut guru BP tersebut peraturan di atas telah dilaksanakan seoptimal mungkin, sebagai contoh siswa yang datang terlambat selalu dikenai peringatan dan sanksi seperti push up atau scotjump. Siswa yang membolos hingga 3 hari berturut akan dipanggil ke ruang BP untuk dinasehati dan diberi peringatan, dan apabila hal tersebut masih berlanjut maka siswa tersebut dapat memperoleh surat peringatan, skorsing atau dipanggil orang tuanya ke sekolah, namun rupanya hal tersebut tidak membuat para siswa jera untuk mengulang perbuatan tersebut.

Senada dengan keterangan guru BP, pada saat peneliti mewawancarai 20 siswa kelas XI mereka mengatakan bahwa memang banyak siswa kelas XI yang sering dipanggil ke ruang BP dari mulai masalah terlambat, membolos, berpakaian tidak sesuai dengan aturan sekolah, atau merokok. Wawancara dengan siswa kelas XI tersebut juga memperoleh informasi bahwa, keduapuluh siswa tersebut merasa keberatan terhadap peraturan yang terlalu ketat yang diberlakukan oleh pihak sekolah, peraturan tersebut adalah mengenai penampilan merupakan peraturan yang paling tidak disukai oleh para siswa, mereka mengatakan bahwa mereka merasa tidak 
dapat mengekspresikan diri dengan ketentuan pakaian yang tidak boleh terlalu kecil atau pendek, rok yang harus di bawah mata kaki, warna sepatu yang harus hitam, kaos kaki yang harus putih, serta rambut yang tidak boleh panjang (bagi siswa lakilaki). Menurut mereka dengan adanya peraturan tersebut banyak dari para siswa yang ditegur dan dipanggil ke ruang BP.

Selain masalah pakaian, membolos juga merupakan jenis pelanggaran yang banyak dilakukan oleh para siswa pasundan 2, khususnya siswa kelas XI. Berdasarkan hasil dari wawancara dengan kedua puluh siswa tersebut, diketahui bahwa 16 siswa pernah membolos, sedangkan 8 siswa diantaranya mengaku sering membolos sehingga pernah diberikan surat peringatan oleh guru BP, alasan mereka pun bermacam-macam, ada dari mereka mengatakan bahwa mereka membolos karena kesiangan dan rumahnya jauh dari sekolah, hal ini mereka lakukan karena apabila mereka tetap berangkat dalam keadaan terlambat maka mereka akan langsung mendapatkan hukuman baik itu push up ataupun scot jump. Selain itu ada juga yang memberikan alasan karena pada hari tersebut terdapat mata pelajaran atau guru yang tidak disukainya, adapula yang memberikan alasan karena mereka memang malas berangkat dan merasa jenuh dengan rutinitas mereka bersekolah. Untuk mensiasati orang tuanya, mereka memberikan berbagai alasan sehingga tidak terkena marah oleh orang tuanya, alasan yang paling sering diungkapkan adalah sakit atau sekolahnya sedang libur, selain itu banyak pula dari mereka yang berpura-pura dari rumah berangkat sekolah namun sebenarnya mereka pergi ke mall atau bermain kerumah temannya yang telah janjian untuk membolos (bagi siswa putri), dan bagi siswa putra biasanya mereka nongkrong ditempat mereka biasa nongkrong atau bermain play station di rental play station.

Hasil wawancara yang berkaitan dengan minat dan partisipasi terhadap kegiatan sekolah diketahui bahwa kedua puluh siswa tersebut tidak aktif dan ikut berpartisipasi terhadap kegiatan sekolah meskipun terdapat 6 siswa yang mengaku sempat berminat dan 2 diantaranya pernah mengikuti ektra kurikuler basket meskipun hanya beberapa bulan pada saat kelas 1. Banyak dari mereka yang mengatakan bahwa mereka malas dan tidak tertarik sedikitpun untuk mengikuti kegiatan sekolah seperti OSIS atau pramuka, sedangkan bagi mereka yang sempat berminat diperoleh 2 alasan, yang pertama adalah karena memang gagal dalam proses seleksi dan yang kedua karena mereka telah malas terlebih dahulu setelah mengetahui bahwa untuk menjadi anggota dalam aktifitas sekolah mereka harus memperoleh tugas-tugas yang berat sebelum akhirnya dilantik menjadi anggota tersebut, dan itupun belum tentu mereka lolos dalam proses seleksi. 
Berdasarkan wawancara yang berkaitan dengan membina relasi yang baik dengan teman sekolah, guru, dan unsur-unsur sekolah diketahui bahwa kedua puluh siswa tersebut memiliki guru yang tidak disukai, dan 12 siswa diantaranya juga memiliki teman yang tidak disukai. Alasan mereka tidak menyukai guru tersebut hampir sama, yaitu karena menurut mereka guru tersebut terlalu disiplin, galak dan selalu memberikan tugas yang sulit dan dalam jumlah yang banyak. Sedangkan bagi mereka yang pernah memiliki masalah dengan temannya mengatakan bahwa mereka bermasalah karena menganggap temannya itu suka ikut campur, cari perhatian, dan arogan, selain itu ada juga dari mereka yang memiliki masalah dengan temannya karena masalah perebutan perempuan atau laki-laki, sehingga mereka sempat tidak bertegur sapa, beradu mulut, hingga bertengkar fisik yang menyebabkan mereka harus menghadap guru BP. Selain itu mereka juga mengatakan bahwa di sekolah ini sering terjadi pemalakan atau terdapat beberapa siswa yang dengan paksa meminta uang pada teman-temannya sendiri, bahkan sekitar beberapa bulan sebelumnya pernah terdapat kasus seorang siswa dipanggil ke ruang BP karena meminta uang dengan paksa dan mengancamnya dengan menggunakan pisau.

Wawancara yang berkaitan dengan kesediaan menerima tanggung jawab, keduapuluh siswa tersebut mengatakan bahwa mereka tidak pernah melaksanakan tugas piket di pagi hari, mereka memberikan alasan karena sekolah tersebut telah memiliki penjaga kebersihan kelas, sehingga pada saat mereka datang di pagi hari kelas mereka telah bersih dan tidak perlu lagi mengerjakan tugas piket. Untuk tugas rumah yang berkaitan dengan pelajaran 8 dari 20 siswa tersebut mengatakan terkadang mereka tidak mengerjakan tugas dengan alasan lupa atau tugas yang diberikan terlalu sulit untuk dikerjakan. Kedua puluh siswa tersebut juga mengatakan bahwa mereka terkadang mencontek baik itu pada saat ulangan atau dalam mengerjakan tugas sekolah, dalam hal mencontek tugas sekolah biasanya mereka lakukan di sekolah, mereka sengaja berangkat pagi sehingga dapat menyalin pekerjaan milik temannya.

Selain hasil dari hasil wawancara mengenai kelima aspek penyesuaian diri diatas peneliti juga mendapatkan data-data berdasarkan observasi di SMA Pasundan 2. Berdasarkan observasi yang dilakukan oleh peneliti diketahui bahwa sebagian besar siswa laki-laki mengeluarkan seragamnya dari celana mereka, sedangkan bagi siswa perempuan berpakaian dengan ketat, kondisi kelas selama jam pelajaran berlangsung tidak pernah dipenuhi oleh para siswa, rata-rata kelas hanya diisi oleh setengah atau sepertiga dari total jumlah siswa di kelas tersebut, saat peneliti mencoba menanyakan kemana siswa yang lain mereka menjawab pergi ke mall, tidak masuk kelas, atau 
sedang di luar kelas, padahal pada saat itu adalah jam pelajaran sekolah. Mereka juga cenderung tidak menghormati guru yang sedang mengajar dengan berbicara sendiri di dalam kelas, bermain game yang ada di handphone, mendengarkan musik dengan menggunakan headset, dan tanpa ragu merias diri atau bercermin di dalam kelas. Hal-hal tersebut diakui guru BP di sekolah itu apabila mereka berhadapan dengan guru-guru tertentu terutama guru yang tidak disukai dan guru yang tidak tegas.

Berkaitan dengan pelanggaran pelanggaran yang dilakukan oleh siswa kelas XI diatas, seorang guru BP yang khusus memegang kelas XI mengatakan bahwa sebagian besar dari para siswa yang melakukan pelanggaran tersebut adalah mereka yang tergolong memiliki keluarga dengan sosial-ekonomi menengah ke bawah.

Berdasarkan informasi dari guru BP tersebut, maka peneliti mencoba untuk mewawancari beberapa siswa diatas, berdasarkan wawancara ini didapatkan informasi bahwa mereka pada umumnya memang termasuk dalam kelas sosialekonomi menengah ke bawah, hal ini dapat disimpulkan dari pendidikan orang tua mereka yang hanya tamatan SMP dan SMA serta dari pekerjaan ayah mereka yang bekerja sebagai sopir angkot, penjual koran, buruh pabrik, satpam, bahkan ada yang menganggur karena mengalami PHK dari tempatnya bekerja. Selain itu ibu mereka juga hanya berstatus sebagai ibu rumah tangga meskipun terdapat beberapa orang yang berdagang makanan kecil-kecilan dan menjadi buruh cuci.

Saat diwawancara mengenai kondisi di rumah, mereka mengatakan bahwa mereka sangat jarang berkomunikasi dan berkumpul bersama-sama dengan keluarga, mereka lebih sering berkumpul dengan teman-temannya di luar rumah atau menyendiri di dalam kamar. Mereka mengatakan bahwa (khususnya laki-laki) mereka berada di luar rumah hanya kurang lebih sekitar 2 jam diluar jam tidur mereka. Sepulang sekolah biasanya hanya ganti baju, makan, kemudian pergi bermain dan kembali menjelang magrib, dan setelah maghrib mereka akan pergi lagi dari rumahnya. Begitu pula dengan sebagian siswa perempuan, sedangkan sebagian lagi biasanya hanya bermain hingga menjelang magrib dan kemudian lebih banyak menghabiskan waktunya di dalam kamar atau menonton TV.

Selain informasi di atas mereka juga mengatakan bahwa di dalam rumahnya tidak terdapat peraturan yang baku mengenai hak dan kewajiban atau tugas-tugas di dalam rumah, kalaupun ada itu hanya jam malam yang diberlakukan khususnya bagi siswa putri, sedangkan bagi siswa putra tidak ada jam malam, bahkan mereka tidak pernah ditanya apabila pulang hingga larut malam. Mereka juga mengatakan tidak ada pembagian tugas yang jelas di dalam rumahnya, sehingga merekapun jarang 
sekali melaksanakan pekerjaan rumah. Mereka hanya mengerjakan ketika dimintai bantuan oleh orang tuanya, meskipun kadang kala mereka juga menolaknya karena malas atau mengerjakannya dengan terpaksa karena tidak ingin mendapatkan teguran dari orang tuanya.

Saat diluar jam sekolah para siswa lebih banyak berada di luar rumah bersama teman-teman sebayanya dibandingkan dengan keluarganya sendiri, yang mereka lakukan di luar rumah biasanya hanya nongkrong bersama teman-temannya di pinggir jalan atau bermain play stasion, kartu, atau domino (bagi siswa putra) sedangkan bagi siswa putri, mereka melakukan aktivitas diluar rumah dengan pergi ke mall atau berkumpul di rumah salah satu temannya.

Dalam tahapan perkembangannya, siswa SMA termasuk dalam masa remaja. Remaja berasal dari kata adolescence yang berasal dari kata dalam bahasa latin adolescere yang artinya tumbuh menjadi dewasa atau tumbuh ke arah kematangan (maturasi). Kata adolesence didefinisikan sebagai suatu periode pertumbuhan antara masa anak dan masa dewasa, periode atau tahapan intermediate antara masa anak dan masa dewasa, periode transisi antara masa anak dan masa dewasa atau diumpamakan merupakan jembatan antara masa anak dengan masa dewasa yang harus dilalui setiap individu sebelum mereka menjadi orang dewasa yang matang, bertanggungjawab dan kreatif. Masa transisi ini mencakup transisi biologis, transisi kognitif dan transisi sosial (Steinberg, 2002). Transisi biologis berkaitan dengan perubahan fisik ke arah kematangan/dewasa. Transisi kognitif berkaitan dengan perubahan kemampuan dalam berpikir. Adapun transisi sosial berkaitan dengan perubahan peran-peran sosial yang harus dimainkan. Masa transisi ini dapat menghabiskan waktu sekitar 10 tahun, dan masa ini dibagi ke dalam sub-tahap remaja awal dari usia 1114 tahun, remaja tengah dari usia 1518 tahun, dan remaja akhir dari 1821 tahun (Steinberg, 2002) yang masing-masing memiliki karakteristik tersendiri. Adapun pembagian ini didasarkan pada duduknya individu di bangku sekolah. Remaja awal duduk di bangku SMP, remaja tengah di bangku SMU, dan remaja akhir di perguruan tinggi atau akademi.

Hill (dalam Steinberg, 2002) menyatakan ada tiga gambaran perkembangan yang terjadi pada remaja, yaitu (1) terjadinya pubertas, (2) munculnya kemampuankemampuan berpikir yang lebih matang, dan (3) adanya transisi ke dalam peranperan baru di masyarakat. Pubertas terjadi pada masa remaja awal. Pubertas adalah periode yang ditandai oleh adanya perubahan fisik. Marshall (dalam Steinberg, 2002) mengungkapkan adanya lima manifestasi fisik perubahan pubertas, yaitu :

1. Adanya pertumbuhan yang sangat cepat (rapid acceleration in growth), yang 
mengakibatkan peningkatan yang dramatis dalam berat dan tinggi badan, sehingga proporsi dan ukuran tubuh berubah menjadi proporsi dan ukuran tubuh orang dewasa..

2. Adanya perkembangan ciri-ciri kelamin primer yaitu adanya perkembangan kelenjar gonad atau kelenjar seks yang mengakibatkan terjadinya perkembangan organ-organ reproduksi laki-laki dan perempuan. Karena organ-organ reproduksi berkembang menjadi fungsional/matang maka individu mempunyai kemampuan untuk memiliki keturunan.

3. Adanya perkembangan ciri-ciri kelamin sekunder yang mencakup perubahan pada genital dan buah dada (pada wanita), dan tumbuhnya rambut-rambut halus pada bagian-bagian tertentu dari tubuh, serta adanya perkembangan lanjutan dari organ-organ reproduksi.

4. Adanya perubahan dalam komposisi tubuh, terutama dalam kuantitas dan distribusi lemak dan otot.

5. Adanya perubahan dalam sistem peredaran darah dan sistem pernapasan, yang memungkinkan individu menjadi bertambah kuat untuk melakukan latihan-latihan fisik.

Hurlock (1992) menyatakan adanya perubahan fisik yang terjadi dengan sangat cepat tersebut memberikan dampak pada individu, yaitu individu mempunyai keinginan yang kuat untuk menyendiri dari teman sebaya atau anggota keluarga; individu merasakan kelelahan fisik dan tidak mau melakukan aktivitas-aktivitas yang sebelumnya disenanginya; individu merasakan gerakan-gerakan tubuhnya canggung dan kaku(tidak luwes); individu merasakan emosinya tidak stabil, mudah meledak dan suasana hatinya mudah berubah-ubah; individu tampak sulit diajak kerjasama, selalu menentang/membangkang serta tidak toleran kepada orang lain; dan individu tampak kehilangan kepercayaan diri. Tugas utama individu yang berada pada tahapan remaja awal adalah menyesuaikan diri terhadap perubahan-perubahan fisik yang terjadi.

Berikutnya terjadi perubahan dalam kemampuan berpikir. Kemampuan berpikir individu menjadi lebih matang daripada periode sebelumnya. Individu menjadi memiliki kemampuan yang lebih baik untuk berpikir tentang hal-hal yang sifatnya hipotetis (sesuatu yang belum terjadi tetapi akan terjadi, atau sesuatu yang tidak terjadi tetapi harus terjadi) dan memiliki kemampuan yang lebih baik untuk berpikir tentang konsepkonsep yang abstrak, seperti persahabatan, demokrasi atau moralitas (Keating dalam Steinberg, 2002). Implikasi dari perubahan kognitif ini sangat jauh. Adanya kemampuan untuk berpikir tentang hal-hal yang sifatnya hipotetis dan abstrak 
mempengaruhi cara berpikir individu tentang dirinya sendiri, relasinya dengan dengan orang lain, dan dunia di sekitarnya. Untuk pertama kalinya individu mampu berpikir secara logis tentang kehidupan yang diinginkannya di masa depan, tentang hubungannya dengan teman-teman dan keluarganya, dan tentang politik, agama dan filsafat. Secara tegas Steinberg (2002) menyatakan bahwa ketika menginginkan informasi-informasi baru remaja berpikir dengan lebih jauh, lebih efisien dan pada umumnya lebih efektif. Hal ini dapat dilihat pada lima karakteristik berpikir remaja, yaitu:

1. Selama masa remaja individu lebih mampu untuk berpikir tentang kemungkinankemungkinan yang akan terjadi. Dengan adanya kemampuan ini muncul kemampuan untuk membuat keputusan, karena dengan dimilikinya kemampuan ini individu menjadi mampu untuk membuat perencanaan-perencanaan, dan memikirkan konsekuensi-konsekuensi dari setiap alternatif pilihan (Steinberg, 2002).

2. Remaja lebih mampu untuk berpikir tentang hal-hal yang sifatnya abstrak yang tidak dapat dilihat secara langsung oleh mata. Dengan adanya kemampuan ini remaja menjadi mampu memahami logika yang abstrak, metafora-metafora dan analogi-analogi. Ia juga mampu menerapkan penalarannya kepada hal-hal yang sifatnya sosial dan ideologi, seperti dalam relasi interpersonal, politik, filsafat, agama dan moralitas topik-topik yang meliputi konsep-konsep yang abstrak seperti persahabatan, keimanan, demokrasi, keadilan dan kejujuran (Steinberg, 2002).

3. Remaja mulai berpikir lebih sering tentang proses berpikir itu sendiri. Individu menjadi mampu memonitor aktivitas kognitifnya sendiri selama proses berpikir. Ia mampu menjelaskan kepada orang lain proses-proses yang ia gunakan. Adanya kemampuan ini membuat remaja mampu melakukan instrospeksi atau mampu berpikir tentang keadaan emosinya sendiri; mampu berpikir tentang bagaimana orang lain berpikir tentang dirinya dan mampu berpikir tentang pikiranpikiran sendiri. Ketiga proses ini memegang peranan penting dalam pertumbuhan psikologis individu, terutama karena membuat remaja mampu melakukan selfexamination dan eksplorasi yang merupakan komponen penting dalam usaha memantapkan sense of identity yang koheren (Steinberg, 2002).

4. Cara berpikir remaja tampak cenderung lebih multidimensional. Maksudnya disini remaja mampu melihat suatu permasalahan dari berbagai sudut pandang. Hal ini membuat remaja memahami bahwa kepribadian seseorang terdiri dari banyak sisi atau membuat remaja memahami bahwa suatu situasi sosial akan 
memiliki interpretasi yang beragam tergantung sudut pandang yang digunakan (Steinberg, 2002).

5. Remaja "melihat" sesuatu secara lebih relatif tidak absolut. Maksudnya di sini remaja cenderung melihat sesuatu tidak "hitam-putih" tetapi mampu melihat sesuatu yang "abu-abu", akibatnya remaja cenderung dapat melihat fakta bukan sebagai suatu kebenaran yang absolut. Karena remaja yakin bahwa segala sesuatu itu relatif, remaja dapat menjadi sangat skeptis tentang segala sesuatu (Chandler dalam Steinberg, 2002) dan mulai meragukan kepastian tentang sesuatu yang sebelumnya telah mereka yakini, dan ini akan membawa pada perasaan bahwa segala sesuatu itu tidak pasti (Steinberg, 2002).

Adanya perubahan dalam kemampuan berpikir tersebut membawa konsekuensi pada remaja yaitu menjadikan remaja mampu berpikir tentang self, tentang siapa dirinya, tentang mau jadi apa kelak dirinya.

Perubahan selanjutnya yang dialami individu pada masa remaja akhir berkaitan dengan transisi sosial, maksudnya adalah perubahan tuntutan sosial dalam hal ini perubahan peran-peran sosial yang diharapkan lingkungan dapat dimainkan oleh individu. Sebagai individu yang siap untuk memasuki masa dewasa, remaja harus belajar mempersiapkan diri untuk peran-peran yang akan dimainkan pada masa dewasa. Tuntutan sosial yang diharapkan dari remaja untuk dapat dipenuhi , tercermin dari tugas-tugas perkembangan remaja.

Menurut Havighurst (dalam Kimmel dan Weiner, 1985) tugas-tugas perkembangan remaja adalah :

1. Mampu menjalin relasi sosial yang lebih matang dengan teman sebaya dari kedua jenis kelamin.

2. Mampu memainkan peran sesuai dengan jenis kelaminnya.

3. Menerima keadaan fisiknya dan dapat menggunakan tubuhnya secara efektif.

4. Mampu mencapai kemandirian secara emosi dari orang tua atau orang dewasa lain.

5. Mempersiapkan diri untuk suatu perkawinan dan kehidupan berkeluarga.

6. Mempersiapkan diri untuk memiliki karir secara ekonomi.

7. Memperoleh seperangkat nilai dan sistem etika sebagai pedoman untuk berperilaku serta mengembangkan suatu ideologi.

8. Berhasrat dan mencapai perilaku sosial yang bertanggung jawab.

Terdapat beberapa masalah dan gangguan-gangguan yang seringkali tejadi masa remaja, masalah-masalah dan gangguan-gangguan tersebut yaitu (Santrock, 2006): 
1. Meminum minuman beralkohol

2. Penyalahgunaan obat-obatan terlarang

3. Merokok

4. Kenakalan remaja (perbuatan yang tidak diterima oleh lingkungan sosial hingga tindakan kriminal)

5. Kehamilan remaja

6. Bunuh diri, dan

7. Gangguan-gangguan makan (Anorexia Nervosa dan Bulimia)

Penyesuaian diri berasal dari kata adaptasi dalam biologi yang berarti usaha individu untuk menyesuaikan diri dengan lingkungan tempat ia hidup. Dalam psikologi ini dikenal dengan kata adjustment (penyesuaian diri), selama hidupnya manusia selalu dituntut untuk menyesuaikan diri dengan lingkungannya. Schneiders (1964) mendefinisikan penyesuaian diri (adjustment) sebagai suatu proses dimana individu berusaha keras untuk mengatasi atau menguasai kebutuhan dalam diri, ketegangan, frustasi, dan konflik, tujuannya untuk mendapatkan keharmonisan dan keselarasan antara tuntutan lingkungan dimana dia tinggal dengan tuntutan didalam dirinya.

Batasan ini mempunyai arti bahwa penyesuaian diri merupakan kemampuan untuk bereaksi secara efektif dan memadai terhadap realitas, situasi dan relasi sosial. Penyesuaian biasanya dibagi menjadi tiga, yaitu :

1. Adjustment di lingkungan keluarga

2. Adjustment di lingkungan sekolah

3. Adjustment di lingkungan masyarakat

Karena dalam hal ini, yang akan diteliti adalah penyesuaian diri di lingkungan sekolah, maka di bawah ini akan dipaparkan mengenai penyesuaian diri di lingkungan sekolah saja. Adapun ciri-ciri penyesuaian diri di lingkungan sekolah yaitu :

1. Mau menerima dan menghormati otoritas sekolah

Mau menerima otoritas sekolah dan mengikuti peraturan-peraturan yang berlaku, dalam hal ini adalah peraturan sekolah, kepala sekolah dan guru tanpa disertai rasa marah dan rasa enggan.

2. Berminat dan berpartisipasi pada aktivitas sekolah.

3. Membina relasi yang baik dengan teman sekolah, guru, dan unsur-unsur sekolah.

4. Mau menerima tanggung jawab.

5. Membantu sekolah dalam mewujudkan tujuan.

Penyesuaian diri di lingkungan sekolah dipengaruhi oleh beberapa faktor, diantaranya adalah lingkungan rumah, dalam hal ini pola asuh orang tua; dan lingkungan sekolah sendiri, dalam hal ini adalah teman sebaya. 
Maccoby (1992) membedakan 4 jenis pola asuh :

1. Authoritative

Orang tua yang autroritative adalah orang tua yang selain hangat juga tegas. Selain memberikan stadar-standar perilaku tertentu bagi anak-anaknya, mereka juga membentuk harapan-harapan yang sesuai dengan perkembangan kebutuhan dan kemampuan anak tersebut. Mereka sangat menghargai kemandirian dan kemampuan untuk mengarahkan diri dan mereka juga menekankan tanggung jawab atas perilaku si anak. Dalam berhubungan dengan anaknya, orang tua yang authoritative mempunyai cara yang rasional, memfokuskan pada permasalahan, sering melakukan diskusi dan penjelasan kepada anak berkaitan dengan masalah disiplin. Orang tua tidak memaksakan kehendak, mereka memberikan kebebasan yang cukup pada anak-anaknya dalam batas-batas yang wajar, namun mereka tetap tegas dan tidak segansegan memberikan batasan-batasan yang tegas. Mereka tidak mudah terpengaruh oleh upaya anak-anak mereka dalam memaksakan kehendak mereka agar terpenuhi.

Disiplin semacam ini memberikan kesempatan pada anak untuk menggali lingkungan dan memperoleh kompetensi interpersonal tanpa ada rasa cemas dan hambatan-hambatan neurotik yang diasosiasikan dengan rasa permusuhan, pembatasan-pembatasan, sewenang-wenang, atau tidak berpengalamannya anak dalam hal menyesuaikan diri dengan lingkungan. Hal ini baik untuk perkembangan self esteem anak, kemampuan adaptasi, perkembangan kompetensi, terinternalisasinya kontrol, dan kepopuleran anak di kalangan temantemannya, serta rendahnya perilaku anti sosial.

2. Authoritarian

Orang tua yang authoritarian menempatkan nilai yang tinggi pada kepatuhan dan konformitas. Mereka cenderung menyukai disiplin yang bersifat menghukum, mutlak, dan memaksa. Keluarga dengan orang tua authoritarian tidak terbiasa dengan komunikasi timbal baik karena menurut orang tua, anak harus menerima aturan-aturan dan standar yang telah ditetapkan oleh orang tua tanpa mempertanyakannya. Mereka cenderung tidak memungkinkan anak untuk berperilaku mandiri. Malahan, mereka lebih menempatkan pentingnya pembatasan atas kemandirian anak. Orang tua semacam ini bersifat kaku, keras, suka menggunakan kekuasaannya, dan tidak responsive terhadap kebutuhankebutuhan anak. Anak dalam keluarga semacam ini kurang memilki control atas lingkungannya dan mendapat sedikit kepuasan Akibatnya, anak menjadi 
tidak bahagia, penuh konflik, dan sering menampakkan perilaku neurotik.

\section{Indulgent}

Orang tua yang indulgent menerima, lunak, dan pasif dalam penerapan disiplin. Mereka memberikan tuntutan yang relatif sedikit terhadap perilaku anak, mereka memberikan kebebasan pada anak bertindak sesuka hati mereka. Orang tua yang indulgent cenderung berpikir bahwa kontrol merupakan sesuatu yang menyalahi kebebasan anak sehingga bisa mengganggu perkembangan yang sehat pada anak. Mereka juga membuat peraturan-peraturan, namun apabila anaknya tidak setuju mereka cenderung bersikap mengalah dan akan menuruti anaknya. Orang tua meberikan kesempatan seluas-luasnya bagi anak untuk mengekspresikan segala keinginan dan pendapat anaknya agar anak dapat memperoleh pengalaman-pengalaman.Tetapi apabila orang tua tidak memberikan pengarahan dan hukuman yang sesuai dengan kesalahan anak, maka hal ini akan mengarahkan anak pada tingkah laku agresif dan egois atau menang sendiri.

4. Neglectful

Orang tua yang neglectful hanya meluangkan waktu dan tenaga yang sangat sedikit untuk berinteraksi dengan anaknya. Bahkan terkadang orang tua bisa dikatakan mengabaikan anak dan tidak peduli dengan keadaan anak. Mereka tidak tahu keadaan anak dan hal-hal yang berkaitan dengan si anak. Mereka jarang bercakap-cakap dengan anak dan jarang mempertimbangkan pendapat anak dalam mengambil keputusan. Mereka membebaskan anak untuk untuk melakukan tindakan yang ingin dilakukan, tidak memberikan tuntutantuntutan pada anak, dan apabila anak melanggar aturan maka akan dibiarkan oleh orang tua. Orang tua juga tidak memikirkan kesejahteraan fisik dan emosi anak. Anak dari keluarga semacam ini merasa ditolak dan tidak diperhatikan karena orang tua membebaskan anaknya untuk melakukan apapun tanpa memberikan bimbingan dan pengarahan. Anak yang mendapat perlakuan ini cenderung lebih agresif, menyimpang, dan tidak menurut pada tuntutan dewasa.

Teman sebaya didefinisikan sebagai individu-individu yang memiliki kedudukan sederajat dengan individu lain. Beberapa ahli perkembangan berpendapat bahwa teman sebaya adalah individu yang sejajar secara sosial, dan untuk beberapa waktu melakukan kompleksitas tingkah laku pada level yang sama (Shaffer, 1994).

Para ahli psikologi mengatakan bahwa teman sebaya tidak hanya diartikan sebagai kumpulan teman bermain, tetapi lebih merupakan perpaduan dari :

1. Interaksi dasar secara reguler. 
2. Mempunyai rasa saling pengertian.

3. Memberikan norma yang spesifik secara implisit dan eksplisit mengenai bagaimana anggota dapat memperkirakan bagaimana bertingkah laku yang baik.

4. Mengembangkan struktur dan hierarki kelompok yang memungkinkan tiap anggotanya untuk dapat bekerja sama kearah tujuan dan prestasi bersama.

Teman-teman sebaya juga menyediakan pola-pola interaksi baru. Mereka mempelajari dan memperbaiki pemikiran-pemikiran, perasaan dan harapan serta tuntutan-tuntutan baru dari lingkungan. Interaksi dengan teman sebaya dapat membantu perkembangan berbagai kompetensi sosial dan personal, hal ini tidaklah mudah diperoleh oleh individu. Kontak dengan teman sebaya dapat memberikan kesempatan untuk memperluas interaksinya dan mengembangkan kompetensi serta pola tingkah laku yang sedikit banyak sama dengan lingkungan dimana individu berada.

Pada masa remaja, remaja lebih berorientasi kepada teman sebayanya. Menurut Berndt \& Medrich (dalam Shaffer, 1994) hal ini terjadi karena pada masa awal remaja, individu lebih banyak menghabiskan waktunya bersama teman sebaya mereka, khususnya dengan teman dekat atau kelompok-kelompok kecil cliques dibandingkan dengan orang tua, saudara, atau orang dewasa yang lain. Cliques sering kali mengembangkan nilai-nilai secara lebih jelas dan bervariasi, dimana nilai-nilai ini menentukan bagaimana cara anggota kelompok berpakaian, berjalan, berfikir, dan bertingkah laku. Remaja usia belasan tahun ini menghadapi tekanan untuk mengikuti semua ketentuan-ketentuan dari kelompok dan akan menanggung resiko diasingkan apabila mereka gagal untuk melaksanakan aturan-aturan tersebut.

Pada masa remaja, kelompok teman sebaya berpotensial untuk menumbangkan pengaruh-pengaruh positif dari orang tua dan guru, sehingga mampu mengembangkan tingkah laku anti sosial. Walaupun demikian perlu diketahui bahwa teman sebaya tidak hanya memberikan pengaruh negatif kepada remaja, karena pengalaman-pengalaman dalam kelompok teman sebaya lebih memiliki kemungkinan untuk memberikan pengaruh yang sehat dan pola tingkah laku yang adaptif dibandingkan pengaruh yang tidak sehat dan munculnya tingkah laku maladaptive.

Bagaimana teman sebaya menggunakan perannya kepada remaja, akan dijelaskan sebagai berikut (Shaffer, 1994):

1. Teman sebaya sebagai penguat sosial (Reinforcement social)

Teman sebaya merupakan sumber yang cukup potensial sebagai penguat tingkah laku remaja, karena teman sebaya dapat memberikankkesamaan status terhadap remaja. Ketika teman sebaya menginstruksikan untuk mengikuti 
beberapa tingkah laku yang diinginkan kelompok dan mengabaikan tingkah laku lain secara signifikan dapat mempengaruhi tingkah laku yang akan dimunculkan remaja. Perilaku individu dapat diperkuat, dipertahankan, ataupun menjadi hilang dengan melihat reaksi yang menyenangkan atau tidak menyenangkan yang diberikan oleh teman sebayanya terhadap tindakan yang dilakukannya.

2. Teman sebaya sebagai model tingkah laku remaja

Pengaruh teman sebaya tidak hanya sebagai penguat dan pemberi hukuman, tetapi juga sebagai social model. Atribut-atribut dan aktivitas-aktivitas lain secara mudah diperoleh dengan mengamati model teman sebaya dalam bertingkah laku. Fungsi lain dari model teman sabaya adalah sebagai informasi bagi individu mengenai bagaimana remaja dapat bertingkah laku pada situasi yang berbeda melalui imitasi dari model-model yang dominan serta anggotaanggota dalam kelompok teman sebaya.

3. Teman sebaya sebagai obyek dalam perbandingan sosial

Remaja sering kali sampai pada kesimpulan-kesimpulan mengenai kemampuan mereka dan aspek-aspek kepribadian lainnya, dengan memperbandingkan tingkah laku dan prestasi mereka dengan teman sebayanya. Hal ini dikarenakan teman sebaya adalah individu yang memiliki usia yang sama, menjadikan teman sebaya lebih merupakan pilihan yang logis bagi perbandingan sosial yang serupa.

4. Teman sebaya sebagai pengkritik dan agen untuk meyakinkan anggotanya

Kelompok teman sebaya sering kali menjadikan tempat untuk mendiskusikan dan memperdebatkan hal-hal yang tidak mereka setujui. Seorang remaja akan lebih mudah dibujuk atau dikriktik oleh teman sebayanya dibandingkan oleh orang tua atau guru. Bujukan dari teman sebaya sering kali dapat mengubah pandangan remaja terhadap sesuatu hal tertentu. Hal ini dilakukan remaja untuk membentuk atau membina suatu hubungan baik dengan kelompok sebayanya.

Melalui keempat peranan teman sebaya diatas, remaja berusaha untuk membina relasi yang baik dengan kelompok teman sebayanya, untuk dapat diterima oleh kelompoknya, remaja akan berusaha mengikuti setiap tingkah laku yang ditampilkan oleh teman-teman kelompoknya.

Dalam hubungannya dengan teman sebaya pada masa remaja, peer conform merupakan ciri khas sosialisasi pada masa remaja. Peer conformity (konformitas terhadap teman sebaya) berarti kecenderungan untuk mengikuti harapan kelompok 
atau mengikuti tindakan kelompok. Maksudnya adalah menerima dan bertingkah laku sesuai dengan nilai dan pola perilaku yang berlaku di dalam kelompoknya. Karena teman sebaya memiliki kedudukan yang penting pada masa remaja, maka remaja akan cenderung menunjukkan konformitas terhadap kelompok teman sebayanya.

Konformitas terhadap kelompok lebih sering ditunjukkan dalam hal perubahan tingkah laku dari pada dalam perubahan pendapat, misalnya dalam hal berpakaian. Kesetiaan pada kelompok dapat dilihat dari bahasa yang digunakan dan tingkah laku yang ditunjukkan oleh anggota kelompok. Jika salah satu anggota berperilaku menyimpang dari norma kelompok, maka anggota tersebut dapat menerima sanksi berupa nerd labelling" (bandel/menympang) atau bahkan sampai "dikeluarkan" atau "ditolak" oleh kelompok tersebut. Oleh karena itu banyak dari remaja yang lebih berusaha untuk dapat diterima sebagai anggota kelompok daripada memelihara hubungan baik dengan orang tua, guru, atau orang dewasa lainnya.

Berdasarkan uraian yang telah dikemukakan diatas maka peneliti tertarik untuk melihat bagaimana gambaran penyesuaian diri di sekolah pada siswa kelas XI SMA Pasundan 2 Bandung serta faktor-faktor penyebabnya.

\section{Metode Penelitian}

Sesuai dengan tujuan penelitian, maka dalam penelitian ini digunakan rancangan penelitian non-eksperimental, dengan metode studi deskriptif. Tujuan dari penelitian deskriptif ini adalah untuk membuat pencandraan (deskriptif) secara sistematis, faktual dan akurat mengenai fakta-fakta dan sifat-sifat dari suatu populasi (Suryabrata, 2003). Metode deskriptif tidak bertujuan untuk menguji suatu hipotesis, melainkan bertujuan untuk membuat deskripsi mengenai hal yang akan diteliti (Suryabrata, 2003). Pada penelitian ini yang akan diteliti adalah penyesuaian diri pada siswa kelas 2 SMA Pasundan 2 Bandung.

Populasi dari penelitian ini adalah seluruh siswa kelas XI SMA Pasundan 2 Bandung yang berjumlah 340 siswa. Pada penelitian ini cara mendapatkan sampelnya yaitu dengan menggunakan cluster random sampling dimana dalam menentukan sampel digunakan dua tahap. Tahap pertama peneliti menentukan terlebih dahulu 5 kelas dari 8 kelas akan dijadikan sampel penelitian dengan cara sampling. Tahap kedua adalah peneliti menentukan siswa-siswa mana saja dari kelima kelas tersebut yang akan dijadikan subyek penelitian secara sampling juga. Dalam menentukan individu tersebut peneliti memberikan peluang yang sama bagi setiap anggota populasi untuk dipilih sebagai sampel dan dalam pengambilan sampel ini dilakukan secara 
acak tanpa memperhatikan strata yang ada dalam populasi tersebut. Jumlah sampel yang akan diambil mengacu pada sampel minimal yang ditetapkan dengan melihat table Krejcie (Sugiyono, 2005) dengan tingkat kepercayaan 95\%. Berdasarkan tabel krejcie dengan jumlah populasi sebanyak 340 siswa maka akan diperoleh sampel sebanyak 181 responden

Untuk mendapatkan data mengenai penyesuaian diri digunakan skala penyesuaian diri di sekolah yang disusun peneliti berdasarkan teori Schneider. Schneider membagi penyesuaian diri di sekolah menjadi 5 aspek, yaitu menerima dan menghormati otoritas sekolah, tertarik dan mau berpartisipasi pada aktivitas sekolah, relasi yang baik dengan teman sekelas, guru, dan unsur-unsur sekolah lainnya, mampu menerima tanggungjawab yang diberikan oleh sekolah, serta membantu sekolah dalam mewujudkan tujuannya.

Adapun untuk memperoleh data penunjang mengenai pola asuh orang tua digunakan angket pola asuh yang disusun berdasarkan teori pola asuh Baumrind; dan untuk mendapatkan data penunjang peran teman sebaya digunakan angket peran teman sebaya yang disusun berdasarkan teori Schaeffer.

Penelitian ini merupakan Penelitian Deskriptif. Teknik analisis yang digunakan adalah Median dan Penaksiran Proporsi. Median dari data penyesuaian diri diperoleh dengan mengurutkan skor semua siswa pada alat ukur penyesuaian diri dari skor yang terendah hingga skor yang paling tinggi. Setelah data diurutkan, maka data yang berada ditengah-tengah lah yang dianggap sebagai data Median. Pada penelitian ini, median alat ukur penyesuaian diri pada sampel siswa kelas XI SMA Pasundan 2 adalah 126 . Siswa yang memiliki skor sama dengan atau dibawah 126 dikelompokkan kedalam kelompok siswa dengan kategori penyesuaian diri yang buruk. Sedangkan siswa dengan skor lebih tinggi dari 126, dikelompokkan kedalam kategori siswa dengan tingkat penyesuaian diri yang baik.

Median dari data peran teman sebaya diperoleh dengan cara membagi dua jumlah seluruh soal (15 soal), sehingga hasil dari pembagian tersebut dianggap sebagai median. Pada penelitian ini, median angket peran sebaya pada sampel siswa kelas XI SMA Pasundan 2 adalah 7,5. Siswa yang memiliki skor diatas 7,5 dikelompokkan kedalam kelompok siswa yang terpengaruh oleh teman sebaya, sedangkan siswa dengan skor kurang dari 7,5 dikelompokkan kedalam kategori siswa yang tidak terpengaruh oleh teman sebaya.

Sedangkan untuk mengkategorikan pola asuh apa yang sesuai dengan individu dilihat jawaban yang terbanyak diantara masing-masing kelompok item yang berkaitan dengan pola asuh tersebut. 
Proporsi adalah ukuran perbandingan yang biasanya dinyatakan dalam porsentase (\%). Dengan menggunakan penaksiran proporsi (porsentase) ini penulis akan mendapatkan kategori tertentu dari variabel yang diteliti (Sudjana, 1996).

Pada penelitian ini penulis membandingkan prosentase antara penyesuaian diri yang baik dan penyesuaian diri yang buruk, kemudian dari masing-masing penyesuaian tersebut, yaitu penyesuaian yang baik dan penyesuaian yang buruk dikorelasikan dengan hasil dari data penunjang yang telah didapatkan oleh penulis, yaitu data pola asuh dan data peran teman sebaya.

\section{Hasil dan Pembahasan}

Tabel. 1

Penyesuaian Diri

\begin{tabular}{ccc}
\hline Penyesuaian Diri & Jumlah & Prosentase (\%) \\
\hline Baik & 86 & $47,5 \%$ \\
\hline Buruk & 95 & $52,5 \%$ \\
\hline Total & 181 & $100 \%$ \\
\hline
\end{tabular}

Keterangan :

Median dari skor penyesuaian diri di sekolah adalah 126

Dari tabel 1 dapat kita lihat bahwa ternyata terdapat lebih dari 50\% siswa kelas XI SMA Pasundan 2 memiliki penyesuaian diri yang buruk di sekolah (tepatnya $52,5 \%$ ). Berdasarkan tabel 2,3,4,5, dan 6 terlihat bahwa ternyata dari kelima aspek yang terdapat dalam penyesuaian diri di sekolah, semuanya menunjukkan bahwa siswa kelas XI SMA Pasundan 2 memiliki penyesuaian diri di sekolah yang buruk di kelima aspek tersebut, baik itu pada aspek menerima dan menghormati otoritas sekolah, mau berpartisipasi dalam aktifitas sekolah, relasi yang baik dengan guru, teman, dan unsur-unsur sekolah, mampu menerima tanggung jawab yang diberikan oleh sekolah, maupun aspek membantu sekolah dalam mewujudkan tujuan. Dari kelima aspek tersebut terlihat bahwa prosentase terbesar dari siswa kelas XI Pasundan 2 dalam ketidakmampuan mereka menyesuaikan diri dengan baik di sekolah adalah pada aspek mau menerima tanggung jawab yang diberikan oleh sekolah. Hal ini terlihat dari tabel 5 yang menunjukkan angka prosentase paling tinggi $(68,0 \%)$ jika dibandingkan dengan aspek-aspek yang lainnya (tabel 2, tabel 3, tabel 4 dan tabel 6). 
Tabel. 2

Gambaran penyesuaian diri aspek

Menerima dan Menghormati Otoritas Sekolah

\begin{tabular}{ccc}
\hline $\begin{array}{c}\text { Menerima dan } \\
\text { Menghormati } \\
\text { Otoritas Sekolah }\end{array}$ & Jumlah & Prosentase (\%) \\
\hline Baik & 87 & $48,1 \%$ \\
\hline Buruk & 94 & $51,9 \%$ \\
\hline Total & $\mathbf{1 8 1}$ & $\mathbf{1 0 0} \%$ \\
\hline
\end{tabular}

Tabel. 3

Gambaran penyesuaian diri aspek

Tertarik dan Berpartisipasi pada Aktivitas Sekolah

\begin{tabular}{ccc}
\hline $\begin{array}{c}\text { Tertarik dan } \\
\text { Berpartisipasi pada } \\
\text { Aktivitas Sekolah }\end{array}$ & Jumlah & Prosentase (\%) \\
\hline Baik & 61 & $33,7 \%$ \\
\hline Buruk & 120 & $66,3 \%$ \\
\hline Total & $\mathbf{1 8 1}$ & $\mathbf{1 0 0 \%}$ \\
\hline
\end{tabular}

Tabel. 4

Gambaran penyesuan diri aspek

Relasi yang Baik dengan Guru, Teman, dan Unsur-unsur Sekolah

\begin{tabular}{ccc}
\hline $\begin{array}{c}\text { Relasi yang baik dengan } \\
\text { guru, teman, dan unsur- } \\
\text { unsur sekolah }\end{array}$ & Jumlah & Prosentase (\%) \\
\hline Baik & 79 & $43,6 \%$ \\
\hline Buruk & 102 & $56,4 \%$ \\
\hline Total & $\mathbf{1 8 1}$ & $\mathbf{1 0 0} \%$ \\
\hline
\end{tabular}


Tabel. 5

Gambaran penyesuaian diri aspek

Menerima Tanggung Jawab yang diberikan Sekolah

\begin{tabular}{ccc}
\hline $\begin{array}{c}\text { Menerima tanggung jawab } \\
\text { dan otoritas sekolah }\end{array}$ & Jumlah & Prosentase (\%) \\
\hline Baik & 58 & $32,0 \%$ \\
\hline Buruk & 123 & $68,0 \%$ \\
\hline Total & $\mathbf{1 8 1}$ & $\mathbf{1 0 0 \%}$ \\
\hline
\end{tabular}

Tabel. 6

Gambaran penyesuaian diri aspek

Membantu Sekolah dalam Mewujudkan Tujuan

\begin{tabular}{ccc}
\hline $\begin{array}{c}\text { Membantu Sekolah } \\
\text { dalam Mewujudkan } \\
\text { Tujuan }\end{array}$ & Jumlah & Prosentase (\%) \\
\hline Baik & 90 & $49,7 \%$ \\
\hline Buruk & 91 & $50,3 \%$ \\
\hline Total & $\mathbf{1 8 1}$ & $\mathbf{1 0 0 \%}$ \\
\hline
\end{tabular}

Dari tabel 7, dapat kita ketahui bahwa faktor teman sebaya ternyata memiliki peran penting dalam menentukan siswa kelas XI SMA Pasundan 2 dalam menyesuaikan diri dengan lingkungan sosialnya di sekolah. Dari tabel 7 dapat terlihat bahwa siswa yang terpengaruh oleh teman sebaya yang berperilaku negatif lebih sulit untuk menyesuaikan dirinya dengan lingkungan sosial di sekolah dibandingkan dengan siswa yang tidak terpengaruh oleh teman sebayanya, hal ini dapat kita ketahui dari prosentase siswa yang terpengaruh hanya $19,8 \%$ yang dapat menyesuaikan diri dengan baik, sedangkan siswa yang tidak terpengaruh oleh teman sebaya mereka dapat menyesuaikan diri dengan lebih mudah, hal ini terlihat dari tingginya prosentase keberhasilan siswa kelas XI yang tidak terpengaruh teman sebaya dalam menyesuaikan diri dengan baik di lingkungan sosialnya $(69,0 \%)$. Selain itu hal ini juga dapat dilihat dari tabel 11, bahwa subyek yang tidak terpengaruh oleh teman sebaya dapat menyesuaikan diri dengan lebih baik dibandingkan dengan subyek yang terpengaruh oleh teman sebaya, baik itu yang dibesarkan oleh pola asuh authoritative, authoritarian, indulgent, ataupun neglectful

Hubungan antara teman sebaya merupakan salah satu bagian dari lingkungan 
sekolah yang dapat mempengaruhi kehidupan sosial, dan moral para remaja, sehingga berpengaruh pula pada penyesuaian diri remaja tersebut, remaja yang mudah terpengaruh dengan teman sebaya akan mudah terbawa oleh pergaulan yang salah. Dari hasil studi yang dilakukan oleh Berdnt (Shaffer, 1994) diketahui bahwa konformitas terhadap kelompok teman sebaya dalam perilaku anti sosial meningkat tajam pada usia 15 tahun, sehingga pada usia ini jika standar atau norma kelompok tidak sesuai dengan norma dan tuntutan sosial, maka peluang remaja yang mudah terpengaruh teman sebaya akan semakin kecil untuk dapat menyesuaikan diri dengan baik.

Selain data di atas, dapat dilihat juga bahwa dari perpaduan antara pola asuh dan peran sebaya yang terbaik untuk menghasilkan penyesuaian yang baik adalah pola asuh authoritative disertai dengan tidak terpengaruhnya individu oleh teman sebaya (lihat tabel 8), hal ini terlihat dengan banyaknya siswa yang dibesarkan dengan pola asuh authoritative serta tidak terpengaruh oleh teman sebaya yang paling banyak dapat menyesuaikan diri dengan baik, yaitu sebesar $85,9 \%$. Individu yang dibesarkan dengan pola asuh authoritative namun terpengaruh oleh teman sebaya belum cukup bagi sebagian besar siswa kelas XI dalam menyesuaikan diri dengan baik, hal ini terlihat dari jumlah prosentase anak dengan pola asuh authoritative namun terpengaruh oleh teman sebaya yang hanya menghasilkan $40,7 \%$.

Diluar dari pola asuh authoritative, dapat kita lihat bahwa baik individu itu terpengaruh ataupun tidak terpengaruh oleh teman sebaya, ternyata lebih sedikit siswa yang penyesuaian dirinya baik apabila dibandingkan dengan individu yang penyesuaian dirinya buruk.

Tabel. 7

Penyesuaian Diri di Sekolah dan Peran Teman Sebaya

\begin{tabular}{cccccc}
\hline \multirow{2}{*}{$\begin{array}{c}\text { Peran Teman } \\
\text { Sebaya }\end{array}$} & \multicolumn{5}{c}{ Penyesuaian Diri } \\
\cline { 2 - 6 } & Baik & $\mathbf{\%}$ & Buruk & \% & Jumlah \\
\hline Terpengaruh & 16 & $19,8 \%$ & 65 & $80,3 \%$ & 81 \\
\hline Tdk Terpengaruh & 69 & $69,0 \%$ & 31 & $31,0 \%$ & 100 \\
\hline Jumlah & $\mathbf{8 5}$ & & $\mathbf{9 6}$ & & $\mathbf{1 8 1}$ \\
\hline
\end{tabular}

Keterangan :

Median dari skor penyesuaian diri di sekolah adalah 126

Median dari skor peran teman sebaya adalah 7,5 
Tabel. 8

Penyesuaian Diri di Sekolah dengan Pola Asuh Authoritative dan Teman Sebaya

\begin{tabular}{ccccccc}
\hline \multirow{2}{*}{ Pola Asuh } & $\begin{array}{c}\text { Peran Teman } \\
\text { Sebaya }\end{array}$ & \multicolumn{5}{c}{ Penyesuaian Diri } \\
\cline { 3 - 7 } & Aaik & \% & Buruk & \% & Jumlah \\
\hline Authoritative & Terpengaruh & 11 & $40,7 \%$ & 16 & $59,3 \%$ & 27 \\
\hline & Tdk terpengaruh & 55 & $85,9 \%$ & 9 & $14,1 \%$ & 64 \\
\hline Authoritarian & Terpengaruh & 3 & $27.3 \%$ & 8 & $72.7 \%$ & 11 \\
\hline \multirow{2}{*}{ Indulgent } & Tdk terpengaruh & 5 & $41.7 \%$ & 7 & $58.3 \%$ & 12 \\
\hline \multirow{2}{*}{ Neglectful } & Terpengaruh & 2 & $8.7 \%$ & 21 & $91.3 \%$ & 23 \\
\hline \multirow{2}{*}{ Jumlah } & Tdk terpengaruh & 1 & $12.5 \%$ & 7 & $87.5 \%$ & 8 \\
\hline & Terpengaruh & 1 & $5.0 \%$ & 19 & $95.0 \%$ & 20 \\
\hline
\end{tabular}

Dari tabel 8 dapat terlihat bahwa faktor pola asuh yang diberikan oleh orang tua dan pengaruh teman sebaya ternyata memberikan pengaruh yang cukup besar terhadap keberhasilan siswa kelas XI SMA Pasundan 2 dalam menyesuaikan diri dengan lingkungan sosialnya di sekolah. Hal ini terlihat dari sebanyak 55 siswa $(85,9 \%)$ yang dibesarkan dengan pola asuh authoritative dan tidak terpengaruh oleh teman sebaya mempengaruhi mereka untuk dapat menyesuaikan diri dengan lingkungan sosial di sekolahnya dengan baik. Sedangkan sisanya, hanya sebanyak 9 siswa yang tidak dapat menyesuaikan diri dengan baik. Menurut Schneider, dari sekian banyak faktor yang mempengaruhi penyesuaian diri, tidak ada satu faktor yang lebih penting dari lingkungan rumah dan hubungan antara orang tua dan anaknya. Hal ini disebabkan interaksi sosial yang pertama diperoleh oleh iindividu adalah di dalam keluarga, yang kemudian dikembangkan di masyarakat. Individu yang dibesarkan dengan pola asuh authoritative memiliki orang tua yang hangat namun juga tegas. Orang tua yang authoritative sangat menghargai kemandirian dan juga menekankan tanggung jawab atas perilaku si anak, mereka juga sering melakukan diskusi dan penjelasan kepada anak-anaknya yang berkaitan dengan masalah disiplin. Mereka memberikan kebebasan yang cukup kepada anak-anaknya dalam batas-batas yang wajar, namun tetap tegas dan tidak segan-segan memberikan batasan-batasan yang tegas. Disiplin semacam ini memberikan kesempatan pada anak untuk memperoleh kompetensi interpersonal tanpa adanya rasa cemas atau neurotic yang diasosiasikan dengan rasa permusuhan, pembatasan-pembatasan, praktek-praktek disiplin yang sewenangwenang, atau tidak berpengalamannya dalam menyesuaikan diri dengan tuntutan- 
tuntutan dan kebutuhan orang lain akibat kebebasan tanpa batas. Pola asuh authoritative juga menyebabkan perkembangan self esteem, kompetentensi, serta kemampuan adjustment anak terhadap lingkungan sosial semakin baik, selain itu juga menurunkan perilaku anti sosial.

Sebaliknya, siswa yang dibesarkan dengan pola asuh selain Authoritative sebagian besar mempengaruhi mereka secara negatif dalam menyesuaikan diri dengan lingkungan sosial mereka. Siswa yang dibesarkan dengan pola asuh authoritarian, indulgent ataupun neglectful menyebabkan mereka tidak dapat menyesuaikan diri dengan baik, baik itu yang terpengaruh oleh teman sebaya maupun tidak.

Siswa yang dibesarkan dengan pola asuh authoritarian memiliki kontrol yang kurang atas lingkungannya, sehingga siswa tersebut mereasa terperangkap dan marah, namun juga merasa takut untuk menampakkannya. Akibatnya, anak menjadi tidak bahagia, penuh konflik, dan sering menampakkan perilaku neurotic sehingga sulit bagi dirinya untuk dapat menyesuaikan diri dengan baik terhadap lingkungan sosialnya.

Siswa yang dibesarkan dengan pola asuh indulgent memperoleh kesempatan dan kebebasan yang seluas-luasnya untuk mengekspresikan segala keinginan dan pendapatnya, namun orang tua tidak memberikan pengarahan atau hukuman yang sesuai dengan kesalahan anak, hal ini menyebabkan anak tidak dapat menerima kegagalan dan nilai-nilai di masyarakat, tingkah laku anak juga mengarah pada tingkah laku agresif, ingin menang sendiri dan egois, sehingga sulit baginya untuk dapat menyesuaikan diri dengan lingkungan sosialnya.

Sedangkan siswa dari keluarga indulgent akan merasa ditolak dan tidak diperhatikan oleh orang tua, mereka diberi kebebasan untuk melakukan apapun tanpa diberikan bimbingan dan pengarahan, sehingga anak tersebut cenderung bertingkah laku lebih agresif, menyimpang, dan tidak menurut pada tuntutan orang dewasa dan lingkungan sosialnya.

\section{Simpulan}

Berdasarkan hasil pembahasan dapat ditarik kesimpulan bahwa sebanyak 86 siswa $(47,5 \%)$ dapat menyesuaikan diri dengan baik terhadap lingkungan sosial di sekolahnya, dan sebanyak 95 siswa (52,5\%) tidak dapat menyesuaikan diri dengan baik terhadap lingkungan sosial di sekolah.

Kondisi penyesuaian diri yang baik di sekolah nampaknya terkait dengan kondisi pola asuh Authoritative. Adapun kondisi penyesuaian diri yang buruk terkait dengan kondisi pola asuh Authoritarian, Indulgent, dan Neglectful. 
Kondisi penyesuaian diri yang baik di sekolah nampaknya terkait juga dengan kondisi tidak berperannya teman sebaya yang berperilaku negatif terhadap individu. Adapun kondisi penyesuaian diri yang buruk di sekolah nampaknya terkait dengan kondisi berperannya teman sebaya yang berperilaku negatif terhada individu.

Data yang telah dijelaskan di atas, didapatkan kesimpulan bahwa sebagian besar individu yang dapat menyesuaikan diri dengan baik adalah individu yang dibesarkan dengan pola asuh Authoritative dan tidak terpengaruh oleh teman sebayanya yang berperilaku negatif.

\section{Daftar Pustaka}

Hurlock, E. B. (1992). Developmental Psychology. $5^{\text {th }}$ Edition. Mc. Graw-Hill, Inc

Kimmel, D. C. dan Weiner, I. B. (1985). Adolescence : a Developmental Transition. New York : John Wiley \& Sons.

Maccoby, E., E. (1992). Social Development : Psychological Growth and Parent Child Relationship. New York : Harcount Brace Javanovich, Inc

Santrock, J. W. (2006). Life-Span Development 10 ${ }^{\text {th }}$ Edition. Mc. New York : Graw-Hill.

Schneider, R. E. (1964). Methods and Materials of Health Education. Philadelphia : Saunders Company.

Shaffer, D. R. (1994). Social and Personality Development. $3^{\text {rd }}$ Edition. California : Brooks / Cole Publishing Company

Steinberg, L. (2002). Adolescence $6^{\text {th }}$ Edition. New York : Mc. Graw-Hill.

Sudjana. (1996). Pengantar Statistik, Edisi kelima. Bandung : Transito.

Sugiyono. (2005). Statistik Untuk Penelitian. Bandung : ALFABETA

Suryabrata, S. (2003). Metodologi Penelitian. Jakarta : PT Raja Grafindo Persada 